\title{
G Antigen 4
}

National Cancer Institute

\section{Source}

National Cancer Institute. GAntigen 4. NCI Thesaurus. Code C104484.

G antigen 4 (117 aa, $\sim 13 \mathrm{kDa}$ ) is encoded by the human GAGE4 gene. This protein may be involved in tumor transformation. 